\title{
Carbohydrate metabolism in the ruminant
}

\author{
Bacterial carbohydrates formed in the rumen and their contribution \\ to digesta entering the duodenum
}

\author{
By A. B. MCALLAN AND R. H. SMITH \\ National Institute for Research in Dairying, Shinfield, Reading $R G 2{ }_{9} A T$
}

(Received 30 April 1973 - Accepted 27 fuly 1973)

\begin{abstract}
I. Samples of mixed bacteria were separated from rumen digesta taken from calves, kept out of contact with adult animals, and from sheep and cows.

2. For calves receiving a diet made up of equal amounts of roughage and cereals with 13-16 g nitrogen $/ \mathrm{kg}$ dry matter, samples of mixed bacteria taken $4-6 \mathrm{~h}$ after feeding contained, on average, $140 \mathrm{~g}$ glucose in $\alpha$-linked polymers ( $\alpha$-dextran), $25 \mathrm{~g}$ galactose and a total of $25 \mathrm{~g}$ other non-glucose, non-galactose sugars (mainly rhamnose, ribose and mannose) in combined forms per $\mathrm{kg}$ dry matter.

3. The $\alpha$-dextran content of similar bacteria samples from sheep or cows receiving diets of similar composition was $70 \mathrm{~g} / \mathrm{kg}$ dry matter. Samples from animals receiving all-roughage diets contained only $25 \mathrm{~g} \alpha$-dextran $/ \mathrm{kg}$ dry matter, but those from cows given more than $70 \%$ of their ration as concentrates (mainly cereal) contained $150 \mathrm{~g} \alpha$-dextran/kg dry matter.

4. Addition of supplementary protein or urea to cereal-roughage diets given to calves greatly depressed the amount of $\alpha$-dextran in the rumen bacterial samples to an average value of $60 \mathrm{~g} / \mathrm{kg}$ dry matter.

5. Samples taken before a morning feed (i.e. after $16 \mathrm{~h}$ fasting) contained less $\alpha$-dextran than samples taken $4^{-6} \mathrm{~h}$ after feeding for both calves and cows.

6. Under different conditions, variations in the amounts of galactose in rumen bacteria sometimes paralleled variations in $\alpha$-dextran. Amounts of other non-glucose sugars did not vary greatly.

7. It was estimated, from a comparison of the compositions of rumen bacteria and duodenal contents, that, in the latter, the rhamnose, ribose and mannose came mainly from the bacteria, the arabinose, xylose and cellulose-glucose mainly from the diet and the galactose and $\alpha$-dextran-glucose from both sources.
\end{abstract}

Although rumen microbes contribute appreciably to the nutrients entering the duodenum of the ruminant, there is little information concerning the composition of mixed rumen bacteria (or protozoa) under different feeding conditions. It has been known for many years that some rumen bacteria can, under certain conditions, accumulate intracellular polysaccharide in vitro (Doetsch, Robinson, Brown \& Shaw, 1953; Gibbons, Doetsch \& Shaw, I955; Hobson \& Mann, I955; Doetsch, Howard, Mann \& Oxford, I957; Thomas, I960; Hungate, I963; Thompson \& Hobson, I97 I). The accumulation depends on the presence of a suitable source of energy in excess of that required immediately for metabolic purposes such as protein synthesis. This excess energy may be supplied by a number of carbohydrates, but the small amount of available evidence suggests that the polysaccharide which accumulates consists mainly of glucose polymers. Apart from the recent work of Jouny \& Thivend $(1972 b)$, there is little information on over-all carbohydrate composition of mixed bacteria developing in the rumen or on the factors influencing the polysaccharide accumulation. The present work is an attempt to provide such information and to assess the relative amounts of bacterial and residual food carbohydrate entering the duodenum of the ruminant. 
Table I. Daily amounts ( $\mathrm{kg})$ of the major components of stall diets given to calves weighing 90-1 $10 \mathrm{~kg}$

$\begin{array}{ccccc}\text { Component } & \text { Diet A } & \text { Diet B } & \text { Diet C } & \text { Diet D } \\ \text { Roughages: Hay and straw } & \text { I.I5 } & \text { I.I5 } & \text { I. I5 } & 0 \cdot 20 \\ \text { Concentrates: Flaked maize } & \text { I.26 } & - & - & 0.95 \\ \text { Barley } & - & \text { I.26 } & - & \text { I.00 } \\ \text { Oats } & - & - & \text { I.26 } & -\end{array}$

For animals at different live weights, these amounts were increased or decreased by about $12 \%$ for each $20 \mathrm{~kg}$ change in live weight.

The concentrates were given in two equal amounts at 09.00 hours and 17.00 hours and were supplemented with vitamins and minerals. Roughages were given at 17.00 hours only.

\section{METHODS}

Animals, feeding and sampling of digesta. Castrated male Friesian calves were weaned at $5^{-8}$ weeks onto a normal calf-rearing concentrates mixture (described by Smith \& McAllan, I966) and hay. At 8-I 5 weeks of age the calves were fitted with rumen cannulas and, in some instances, a simple cannula in the proximal duodenum. The cannulas were as described by Smith \& McAllan (1970). At least 3 weeks were allowed after the operations and 9 weeks after weaning before experiments to sample digesta were begun. During the experimental period, the calves, aged 14-42 weeks, were given one or other of the diets shown in Table $I$, all of which provided similar intakes of metabolizable energy sufficient for a gain of about $0.4 \mathrm{~kg} / \mathrm{d}$. Unless otherwise stated, the calves were kept out of direct contact with adult animals in a calf unit equipped with concrete or metal pens with expanded-metal floors. This will be referred to subsequently as environment $A$ in accordance with our usage in a previous paper (Smith \& McAllan, 1974).

Friesian cows, aged about 3.5 years, and crossbred wethers, aged about I. 5 years, all equipped with rumen cannulas (Balch \& Cowie, rg62), were also used. The cows received varying proportions of dairy cubes and hay. The composition of the dairy cubes (largely barley and maize with protein and mineral supplements) is described by Smith \& McAllan ( 1970 ). The sheep were given diets consisting of varying proportions of one of two dairy mixes and hay. One dairy mix was identical in composition to the dairy cubes described above, and the other was of similar composition but with wheat in place of maize.

Samples of rumen and duodenal digesta were obtained from the calves, sheep and cows as described by Smith \& McAllan (I970).

Mixed rumen bacteria were separated from rumen digesta as described by Smith \& McAllan (1974).

\section{Analytical methods}

Carbohydrates. Nearly all the carbohydrates in digesta samples from the rumen or duodenum and in rumen bacteria, consist of sugars in combined forms, most as polysaccharides. Preliminary experiments were carried out to determine the best hydrolysis conditions for achieving maximum recovery of these constituent sugars. Samples after hydrolysis were analysed as follows. Hydrolysates were neutralized 

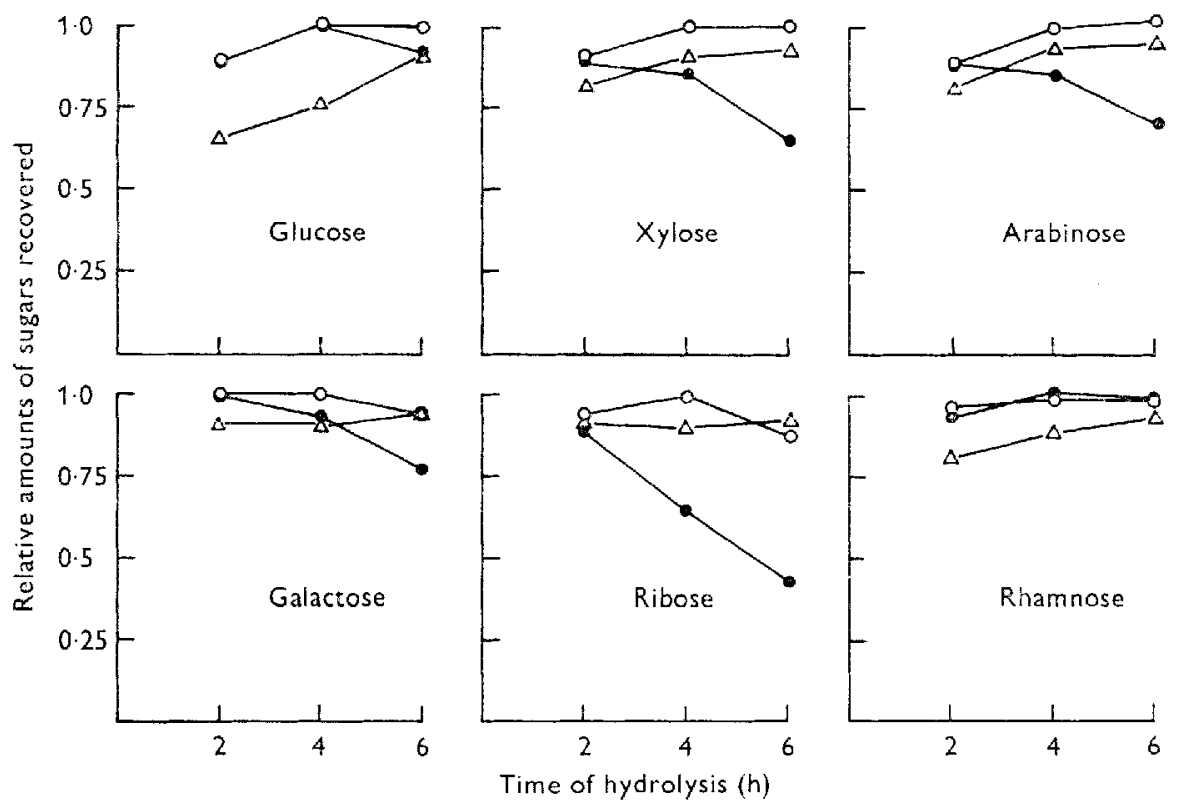

Fig. I. Amounts of sugars released from calf duodenal digesta after hydrolysis at $100^{\circ}$ for varying times in $\mathrm{H}_{3} \mathrm{SO}_{4}$ at a final concentration of $0.25 \mathrm{M}(\triangle), 0.5 \mathrm{M}(\mathrm{O})$ or $\mathrm{I} \cdot \mathrm{O} \mathrm{M}(\boldsymbol{C})$. The digesta samples were obtained from a calf given diet A (Table I) and the results for each sugar are expressed as a proportion of the total released after hydrolysis for $4 \mathrm{~h}$ at $100^{\circ}$ in $0.5 \mathrm{M}-\mathrm{H}_{2} \mathrm{SO}_{4}$.

with $\mathrm{Ba}(\mathrm{OH})_{2}$ to $\mathrm{pH} 7.0$, filtered and passed through a column ( $150 \mathrm{~mm} \times 5 \mathrm{~mm}$ ) of Dowex $\mathrm{I} \times 4$ ion exchange resin, 50-100 mesh, in the chloride form. Boric acid was added to the solution which emerged from the column to a final concentration of $0 . \mathrm{I} \mathrm{M}$, to convert the sugars into their borate complexes. The resulting mixture of these complexes was separated by high-pressure anion-exchange chromatography and the different sugars in the column effluent were determined by an orcinol colour reaction as described by Smith \& McAllan (1969). In this way rhamnose, ribose, mannose, arabinose, galactose, xylose and glucose were determined in the hydrolysate.

Results obtained under different conditions of hydrolysis are given in Fig. I for duodenal contents. Similar recovery results were obtained for mixed bacterial samples from a more limited study of hydrolysis conditions. It was concluded that hydrolysis for $4 \mathrm{~h}$ at $100^{\circ}$ in $0.5 \mathrm{M}-\mathrm{H}_{2} \mathrm{SO}_{4}$ was most suitable for the materials being examined. Recoveries from solutions of pure sugars which were subjected to those conditions were $97-$ Ior $\%$ for arabinose, mannose, galactose, rhamnose, xylose and glucose. Ribose showed a small but consistent loss of about ro\%. Recovery of glucose from samples of potato, maize and wheat starches hydrolysed in this way was nearly complete (mean value $96 \pm 4 \%$ for six experiments, two for each starch). There was very little (less than $3 \%$ ) release of glucose from pure cellulose treated similarly. The glucose released during the investigations of hydrolysis conditions was also estimated enzymatically by an automated glucose-oxidase:peroxidase procedure (Biochemica Test Combination TBAP 15756 ; the Bochringer Corporation (London) 
Ltd). These results were very similar to the chromatographic values, but consistently lower by about $4 \%$.

A comparison was made with twelve samples of sheep duodenal digesta between the content of $\alpha$-linked glucose polymer determined by enzymatic release, according to the procedure of MacRae \& Armstrong (1968), and glucose released during

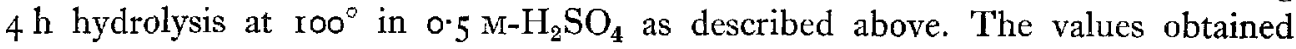
by the chromatographic procedure were similar to, but consistently slightly higher than, those obtained by $\alpha$-amyloglucosidase reaction. The former were rog $\pm 6 \%$ (mean value \pm SEM) of the latter. It is concluded, therefore, that glucose released by

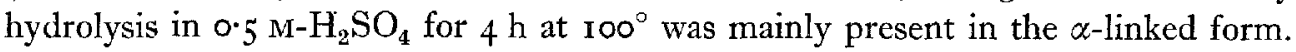
Glucose released in this way from bacteria will be referred to as $\alpha$-dextran-glucose.

The residue from the hydrolysis with $0.5 \mathrm{M}-\mathrm{H}_{2} \mathrm{SO}_{4}$ described above, was washed with water, dried, weighed and ground to a fine powder. A portion of the ground, well-mixed residue ( $100-250 \mathrm{mg}$ ) was stirred with $5 \mathrm{ml}$ of $\mathrm{I}_{3} \mathrm{M}_{-} \mathrm{H}_{2} \mathrm{SO}_{4}$ at $30^{\circ}$ for $45 \mathrm{~min}$. After this time $140 \mathrm{ml}$ water were added, giving a final concentration of $0.45 \mathrm{M}-\mathrm{H}_{2} \mathrm{SO}_{4}$, and the mixture was heated in an autoclave for $\mathrm{xh}$ at $\mathrm{I} 5 \mathrm{lb} / \mathrm{in}^{2}\left(\mathrm{r} 20^{\circ}\right)$, cooled, neutralized with $\mathrm{Ba}(\mathrm{OH})_{2}$ to $\mathrm{pH} 7.0$ and filtered. The glucose released, which will be referred to as cellulose-glucose, was estimated by the automated glucose-oxidase:peroxidase procedure mentioned previously. The only other sugar detected in this hydrolysate was xylose, present to an extent of about $5 \%$ of the total xylose released during mild hydrolysis. Recovery of glucose from cellulose, in three experiments in which cellulose was passed through the complete hydrolysis procedure was $93 \pm 4 \%$.

Nucleic acids. RNA and DNA were determined by the procedure of McAllan \& Smith (1969).

\section{RESULTS}

\section{Carbohydrate composition of mixed rumen bacteria}

Calves (kept in environment $A$ ). Amounts of sugars liberated by acid hydrolysis of samples of mixed bacteria separated from rumen digesta from nine calves are shown in Table 2. The samples were taken $4^{-6} \mathrm{~h}$ after a morning feed from animals being given diet $\mathrm{A}$ (Table $\mathrm{I}$ ). This diet contained $\mathrm{I} 6 \mathrm{~g}$ nitrogen $/ \mathrm{kg}$ dry matter. Appreciable amounts of $\alpha$-dextran-glucose were found to be present. Of the other sugars present, rhamnose and galactose were present in the greatest amounts ranging from 8 to 22 and from $\mathrm{I} 4$ to $40 \mathrm{~g} / \mathrm{kg}$ bacterial dry matter respectively. Ribose (almost certainly from RNA) and mannose were present in small amounts of the order of $3^{-10} \mathrm{~g} / \mathrm{kg}$ dry matter. Arabinose, xylose and cellulose-glucose were present in very small amounts, normally less than $5 \mathrm{~g} / \mathrm{kg}$ dry matter. Much of these latter sugars probably represented a small degree of contamination by food constituents. In further examinations these sugars were always found to be present in very small amounts; their values are omitted from subsequent results. The amounts of rhamnose, ribose, mannose and galactose are frequently recorded together as total non-glucose sugars.

The results shown in Table 2 were for animals given diet A (Table $\mathrm{I}$ ) in which the roughage component was hay. In other experiments with five calves the hay was 


\section{Table 2. Carbohydrates in mixed bacteria from the rumens of calves}

(Samples were taken $4^{-6} \mathrm{~h}$ after calves, kept out of direct contact with adult animals (environment A), were given $\operatorname{diet} A$ (Table 1 ) in which the roughage component was hay and which contained $\mathrm{I} 6 \mathrm{~g}$ nitrogen $/ \mathrm{kg}$ dry matter. Results are expressed as $\mathrm{g} / \mathrm{kg} \mathrm{dry}$ bacterial cells)

\begin{tabular}{|c|c|c|c|c|c|}
\hline \multirow[b]{2}{*}{ Carbohydrate } & \multirow{2}{*}{$\begin{array}{l}\text { No. of } \\
\text { calves } \\
\text { (c) }\end{array}$} & \multirow{2}{*}{$\begin{array}{l}\text { No. of } \\
\text { samples } \\
(n)\end{array}$} & \multicolumn{3}{|c|}{ Bacterial carbohydrate content } \\
\hline & & & Mean & $\mathrm{SE}$ & $\mathrm{df}$ \\
\hline Rhamnose & 9 & 30 & I $2 \cdot 1$ & $1 \cdot 59$ & 8 \\
\hline Ribose & 9 & 30 & $6 \cdot 1$ & 0.53 & 8 \\
\hline Mannose & 9 & 30 & 41 & 0.45 & 8 \\
\hline Arabinose & 9 & 30 & $2 \cdot 6$ & 0.64 & 8 \\
\hline Galactose & 9 & 30 & $2 I \cdot 9$ & 3.17 & 8 \\
\hline Xylose & 9 & $3^{\circ}$ & $2 \cdot I$ & 0.33 & 8 \\
\hline$\alpha$-dextran-glucose & 9 & 30 & $132 \cdot 2$ & 8.06 & 29 \\
\hline Cellulose-glucose & 3 & 8 & $3 \cdot 1$ & 0.48 & 7 \\
\hline
\end{tabular}

For rhamnose, ribose, mannose, arabinose, galactose and xylose there were significant differences $(P<0.10)$ between calves relative to samples from the same calf. For these sugars the SE of the mean is derived from the unweighted variation between calf means with $(c-\mathrm{I}) \mathrm{df}$. For the other two sugars calf differences were not significant and the SE is derived from the total variation between samples, irrespective of calves, with $(n-I) \mathrm{df}$.

\section{Table 3. Effect of nitrogen supplementation of the diet on the $\alpha$-dextran-glucose content of mixed rumen bacteria of calves}

(Samples were taken $4-6 \mathrm{~h}$ after the 09.00 hours feed from calves kept out of contact with adult animals (environment $\mathrm{A}$ ). Results are expressed as $\mathrm{g} / \mathrm{kg}$ dry bacterial cells and are mean values with their standard errors, with total numbers of observations in parentheses)

\begin{tabular}{|c|c|c|c|c|c|c|}
\hline \multirow[b]{3}{*}{$\begin{array}{l}\text { No. of } \\
\text { calves }\end{array}$} & \multirow[b]{3}{*}{$\begin{array}{c}\text { Basal } \\
\text { diet }\end{array}$} & \multirow[b]{3}{*}{$\begin{array}{c}\text { Type of } \\
\text { supplement }\end{array}$} & \multicolumn{4}{|c|}{ Bacterial $\alpha$-dextran-glucose content } \\
\hline & & & \multirow[b]{2}{*}{$\begin{array}{l}\text { Unsupplemented } \\
\text { cereal feed: } \\
\text { I } 6 \mathrm{~g} \mathrm{~N} / \mathrm{kg} \text { dry } \\
\text { matter }\end{array}$} & \multicolumn{3}{|c|}{ Supplemented feeds: } \\
\hline & & & & $\begin{array}{c}20-3 \circ \mathrm{g} \\
\mathrm{N} / \mathrm{kg} \text { dry } \\
\text { matter }\end{array}$ & $\begin{array}{c}3 \mathrm{I}-40 \mathrm{~g} \\
\mathrm{~N} / \mathrm{kg} \text { dry } \\
\text { matter }\end{array}$ & $\begin{array}{l}4 \mathrm{I}-5^{2} \mathrm{~g} \\
\mathrm{~N} / \mathrm{kg} \mathrm{dry} \\
\text { matter }\end{array}$ \\
\hline 2 & A & Urea & $160 \cdot 2 \pm 20 \cdot 4(7)$ & - & $\ldots$ & $72 \cdot 6 \pm 7 \cdot 6(6)$ \\
\hline I & $A^{*}$ & Maize gluten & $157 \cdot 2 \pm 6 \cdot 3(4)$ & - & - & $70 \cdot 3 \pm 6 \cdot 2(4)$ \\
\hline 2 & $A^{*}$ & Casein & $144.9 \pm 17 \cdot 5(4)$ & $84.4 \pm 9 \cdot 4(4)$ & $45 \cdot 8 \pm 7 \cdot 8(4)$ & $47 \cdot 5 \pm 9 \cdot \circ(6)$ \\
\hline 1 & $A^{*}$ & $\begin{array}{l}\text { Decorticated } \\
\text { groundnut meal }\end{array}$ & $140 \cdot 3(1)$ & $109 \cdot 3(\mathrm{r})$ & - & 一 \\
\hline I & $D^{*}$ & $\begin{array}{l}\text { Decorticated } \\
\text { groundnut meal }\end{array}$ & $135^{\prime} 8 \pm 15^{\prime 2}(3)$ & - & $70 \cdot 9 \pm 6 \cdot 0(5)$ & - \\
\hline I & $D^{*}$ & Fish meal & I $35 \cdot 8 \pm 15 \cdot 2(3)$ & - & $89 \cdot 2 \pm 5 \cdot 5(6)$ & - \\
\hline
\end{tabular}

* Part of the flaked maize in the diets was replaced by the nitrogen supplement, keeping the energ. intake (starch equivalent) the same as in the basal diet (Table I).

replaced by an equal intake of straw. Mean values ( \pm SEM) from ten experiments (two with each calf) for rhamnose, galactose and $\alpha$-dextran-glucose were $14.5 \pm 2.5$, $30.3 \pm 5.7$ and $153 \cdot 3 \pm 1 r^{\circ} \cdot \mathrm{g} / \mathrm{kg}$ bacterial dry matter, not appreciably different from the values obtained for the calves receiving hay (Table 2 ).

Variation in the type of dietary cereal was also examined. Samples of mixed bacteria were separated from the rumen of a calf being given oats (diet C, Table $\mathrm{I}$ ) 


\section{Table 4. Carbohydrates in mixed samples of bacteria separated from the rumens of sheep and cows}

(Samples were taken 4-6 h after giving diets of hay + concentrates ( $32-62 \%$ hay), or all hay, which contained I6-19 g nitrogen/kg dry matter. Results are mean values with their standard errors expressed as $\mathrm{g} / \mathrm{kg}$ dry bacterial cells)

\begin{tabular}{|c|c|c|c|c|c|}
\hline Animal & Diet & $\begin{array}{l}\text { No. of } \\
\text { animals }\end{array}$ & Rhamnose & Galactose & $\begin{array}{l}\alpha \text {-dextran } \\
\text { glucose }\end{array}$ \\
\hline Cow & $\begin{array}{l}\text { Concentrates + hay } \\
\text { All hay }\end{array}$ & $\begin{array}{l}3 \\
2\end{array}$ & $\begin{array}{l}12 \cdot 5 \pm 1 \cdot 3 \\
13 \cdot 0 \pm 4 \cdot 8\end{array}$ & $\begin{array}{l}10.9 \pm 1.4 \\
13.5 \pm 0.4\end{array}$ & $\begin{array}{l}77 \cdot 4 \pm 24 \cdot 3 \\
30 \cdot 8 \pm \text { I I.5 }\end{array}$ \\
\hline Sheep & $\begin{array}{l}\text { Concentrates + hay } \\
\text { All hay }\end{array}$ & $\begin{array}{l}3 \\
7\end{array}$ & $\begin{array}{r}10 \cdot 2 \pm 1 \cdot 4 \\
8 \cdot 4 \pm 0.2\end{array}$ & $\begin{array}{r}8 \cdot 1 \pm 1 \cdot 1 \\
10 \cdot 2 \pm 0.8\end{array}$ & $\begin{array}{l}6 I \cdot 3 \pm 13 \cdot 6 \\
I 7 \cdot 1 \pm 2 \cdot 4\end{array}$ \\
\hline
\end{tabular}

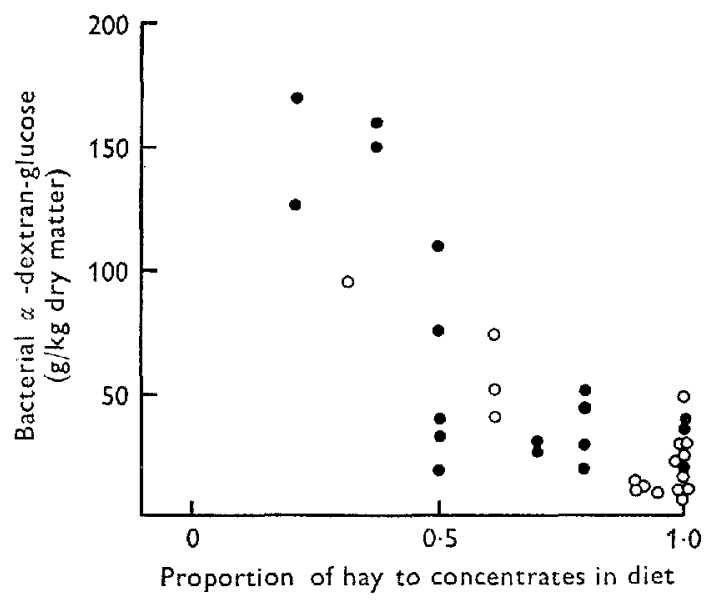

Fig. 2. Effect of differences in dietary carbohydrate content on the $\alpha$-dextran-glucose content of samples of mixed bacteria separated from rumen contents. All samples were taken $4^{-6} \mathrm{~h}$ after giving diets containing I6-19g nitrogen/kg dry matter to cows (O) and sheep (O).

or barley (diet B, Table I). Mean values for the carbohydrate composition of the bacteria in three experiments with each of these diets were $(\mathrm{g} / \mathrm{kg}$ bacterial dry matter for oats and barley respectively): rhamnose $13.7 \pm 4 \cdot 4$ and $\mathrm{II}_{4} \pm \pm 1 \cdot 5$; galactose I $I \cdot 8 \pm 2 \cdot 4$ and $13 \cdot 3 \pm 0 \cdot 3 ; \alpha$-dextran-glucose $140 \cdot 6 \pm 16 \cdot 6$ and $157 \cdot 8 \pm 2 \cdot 9$.

Values presented so far for composition of bacterial carbohydrate have been for samples obtained from animals given diets with a nitrogen content of ${ }^{3-\mathrm{I} 6 \mathrm{~g} / \mathrm{kg}}$ dry matter. Results of experiments to determine the effect of increased nitrogen intake on bacterial sugars are shown in Table 3 . Values for the unsupplemented cereal foods (containing $16 \mathrm{~g}$ nitrogen/ $\mathrm{kg}$ dry matter) were similar to those found previously (Table 2). At all levels of supplementation, however, regardless of the source of nitrogen, there were marked decreases in the amounts of $\alpha$-dextran-glucose in the rumen bacteria. Galactose in the bacteria was often similarly reduced. For example, when the basal diet was supplemented with casein to give $4 \mathrm{I}-52 \mathrm{~g}$ nitrogen $/ \mathrm{kg}$ dry matter the galactose content of the bacteria was decreased from $27 \cdot 2$ to $9 \cdot 5 \mathrm{~g} / \mathrm{kg}$ bacterial dry matter. Other non-glucose sugars showed no consistent variation. 


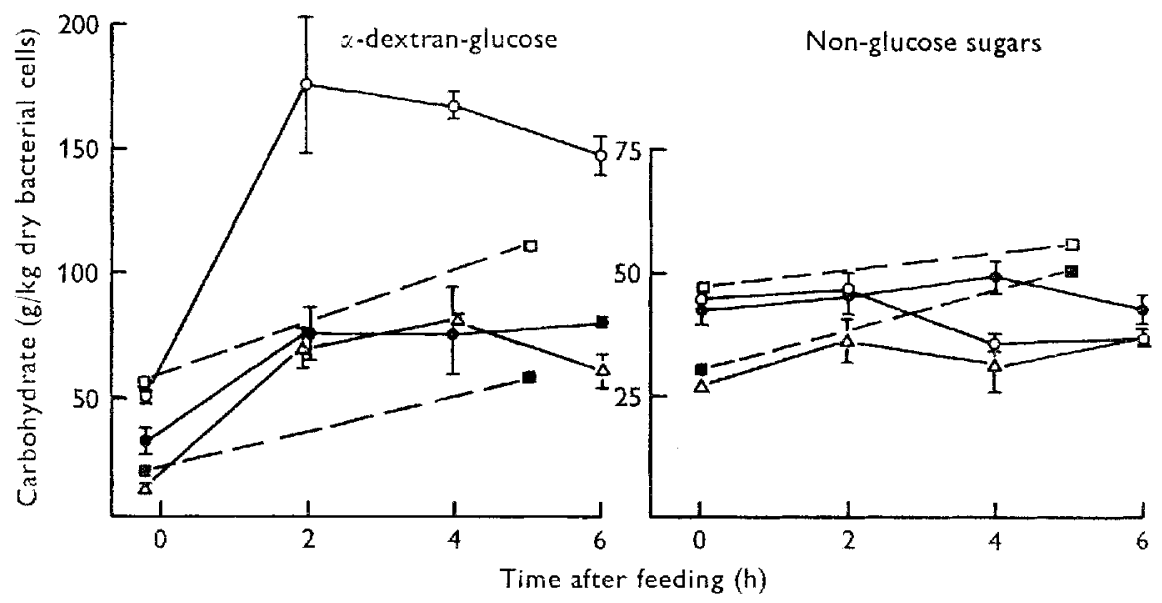

Fig. 3. Variation, after feeding, in carbohydrate composition of mixed bacteria separated from rumen digesta of calves kept out of contact with adult animals (environment $\mathrm{A}$ ). Results for $\alpha$-dextran-glucose and total non-glucose sugars, expressed as $\mathrm{g} / \mathrm{kg}$ bacterial dry matter, are mean values for two experiments with one calf receiving $\operatorname{diet} A(O)$, $\operatorname{diet} A$ supplemented with urea ( $)$ or maize gluten $(\triangle)$ described in Tables $\mathrm{I}$ and 3 . The vertical bars represent standard errors of the mean. Also shown are single experiment values for a sccond calf ro ceiving diet $A(\square)$ and $\operatorname{diet} A$ supplemented with decorticated groundnut meal ( $(\mathbf{D})$.

Sheep and cows. Since samples of mixed bacteria separated from the rumen digesta of sheep and cows were collected from animals being used in experiments designed to study factors other than carbohydrate metabolism, the diets were quite varied. Results given in Table 4 include values for samples from animals given concentratehay diets fairly similar to those given to the calves shown in Table 2. Both sheep and cow samples had a markedly lower $\alpha$-dextran-glucose content than those of the calves kept in environment $A$. The values were, however, similar to those found for bacteria from calves reared in contact with adult sheep or cows (Smith \& McAllan, 1974). Concentrations of total non-glucose sugars did not differ greatly between the different groups of animals and were similar to those presented for cows by Jouany \& Thivend $(1972 b)$. Results obtained from bacteria from sheep and cows given diets with different proportions of roughage and concentrates are shown in Table 4 and in Fig. 2. It appeared that for diets containing only hay, rumen bacteria contained only small amounts of $\alpha$-dextran-glucose, but that for the dietary nitrogen content stated, bacterial $\alpha$-dextran content increased with diets containing increasing proportions of concentrates. Total non-glucose sugars remained in the range $30-5^{\circ}$ $\mathrm{g} / \mathrm{kg}$ dry matter irrespective of the diet.

Variation of bacterial carbohydrates after feeding. Variation after feeding in the $\alpha$-dextran-glucose content of mixed bacteria separated from the rumens of calves given diets of different nitrogen content are shown in Fig. 3. Samples taken immediately before the morning feed (after $16 \mathrm{~h}$ fasting) had $\alpha$-dextran-glucose contents approximately $30 \%$ of the values obtained after feeding on the diets examined. The total non-glucose sugars showed no such marked changes, and the values obtained were 


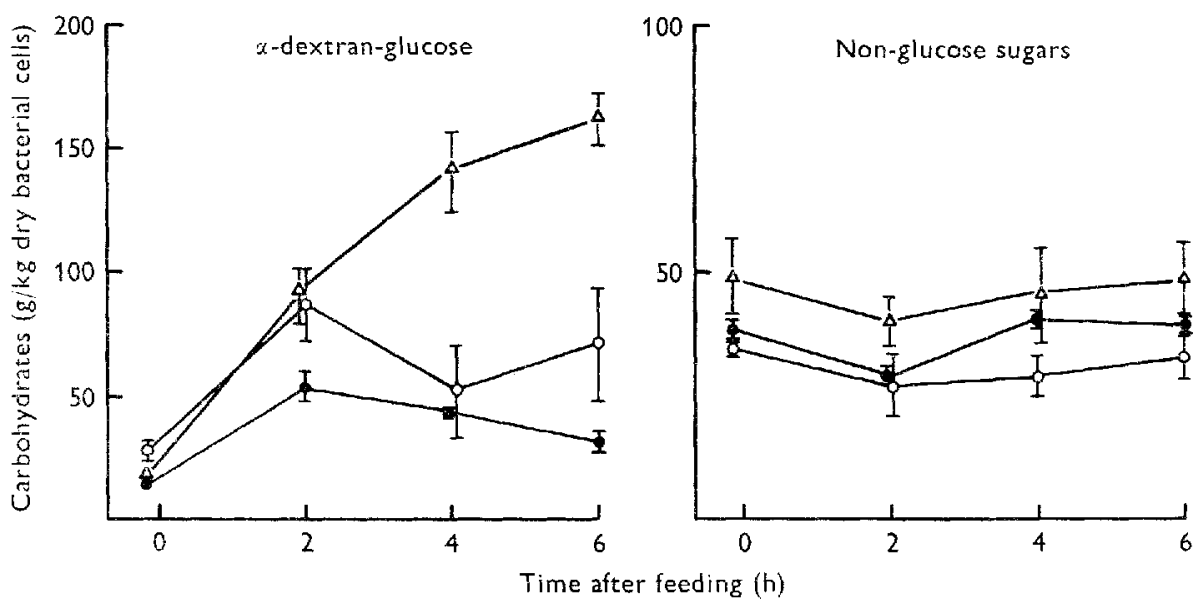

Fig. 4. Variation after feeding in the carbohydrate composition of mixed bacteria separated from the rumens of cows receiving diets containing $\mathrm{I} 3-\mathrm{I} 9 \mathrm{~g}$ nitrogen $/ \mathrm{kg}$ dry matter. Results are mean values for two experiments with two cows receiving diets containing less than $300 \mathrm{~g}$ hay $/ \mathrm{kg}$ (one experiment with each animal) $(\Delta)$, two experiments with two cows receiving diets containing equal proportions of hay and concentrates (one experiment with each animal) (O), and three experiments with two cows receiving diets containing more than $80 \%$ hay (e). The vertical bars represent standard errors of the mean.

very similar to those quoted earlier for other calves. Corresponding values for rumen bacteria separated from cows given diets of fixed nitrogen, but varying carbohydrate intakes, are shown in Fig. 4. As was found for the calves, samples of bacteria taken before feeding contained less $\alpha$-dextran than those taken $4^{-6} \mathrm{~h}$ after feeding, the increase after feeding was most marked in the experiments in which a diet containing more than $70 \%$ concentrates was given. Non-glucose sugar concentrations showed little or no diurnal variation.

\section{Contribution of bacterial carbohydrates to digesta entering the duodenum}

Of the total carbohydrate entering the ruminant duodenum, part is of dietary origin and has escaped fermentation in the rumen, and part is bacterial in origin. To determine the relative amounts of these contributions, nucleic acids were used as indices of the microbial contribution (Smith, I969; McAllan \& Smith, I97I). It has been shown that there is no loss of bacterial nucleic acids during passage of digesta from the rumen to the duodenum (Smith \& McAllan, 1971) and that dietary nucleic acids ingested by ruminants are rapidly broken down (McAllan \& Smith, r973). By establishing the ratio of individual carbohydrates to nucleic acids in samples of mixed rumen bacteria and assuming these to be representative of the whole microbial population, it is possible to estimate the concentration of microbial carbohydrates at the duodenum from the nucleic acid concentration at that site.

In experiments with a calf kept in environment $A$, nucleic acid and carbohydrate were determined in samples of mixed bacteria separated from rumen contents and in whole duodenal digesta taken $\mathbf{I}-\mathbf{2} \mathbf{h}$ later. Three experiments were done with each of three diets (diets A, B and C, Table I). Results for one such experiment are 


\title{
Table 5. Contribution of bacterial carbohydrates to total carbohydrates entering the duodenum of the calf
}

\begin{abstract}
(Values in the first two columns are for a single experiment in which a calf was given diet $\mathrm{A}$ (Table $x$ ) and show the proportions of combined sugar contents to RNA contents for samples of mixed rumen bacteria taken $4 \mathrm{~h}$ after feeding and duodenal digesta taken $2 \mathrm{~h}$ later. Amounts of RNA in the samples were 32.5 and $16.8 \mathrm{~g} / \mathrm{kg}$ dry matter respectively. The fourth column shows estimates from those results of the proportions of the different sugars in the duodenal digesta that were derived from the bacteria. The fifth column shows mean values with their standard errors for similar estimates in nine experiments in which a calf was given $\operatorname{diet} \mathrm{A}, \mathrm{B}$ or $\mathrm{C}$ (Table I); three experiments on each diet)
\end{abstract}

\begin{tabular}{|c|c|c|c|c|}
\hline \multirow[b]{2}{*}{ Carbohydrate } & \multirow[b]{2}{*}{$\begin{array}{c}\text { Sugar: RNA } \\
\text { in rumen } \\
\text { bacteria ( } 1 \text { ) }\end{array}$} & \multirow[b]{2}{*}{$\begin{array}{c}\text { Sugar: RNA } \\
\text { in duodenal } \\
\text { digesta (2) }\end{array}$} & \multicolumn{2}{|c|}{$\begin{array}{l}\text { Estimated bacterial contributio } \\
\text { to the duodenal contents }\end{array}$} \\
\hline & & & $\begin{array}{l}\text { For single } \\
\text { experiment } \\
\quad(1 \div 2)\end{array}$ & $\begin{array}{l}\text { For } \\
\text { nine similar } \\
\text { experiments }\end{array}$ \\
\hline Rhamnose & $0 \cdot 3 \mathrm{I}$ & 0.37 & 0.84 & $0.90 \pm 0.11$ \\
\hline Ribose & 0.29 & 0.25 & $I \cdot I 6$ & $I \cdot 38 \pm 0.09$ \\
\hline Mannose & 0.08 & 0.10 & 0.80 & $0.96 \pm 0.16$ \\
\hline Arabinose & 0.16 & 0.98 & 0.16 & $0.06 \pm 0.02$ \\
\hline Galactose & 0.43 & 0.68 & 0.63 & $0.44 \pm 0.07$ \\
\hline Kylose & 0.23 & $3 \cdot 26$ & 0.07 & $0.03 \pm 0.01$ \\
\hline c-dextran-glucose & $5 \cdot 10$ & $7 \cdot 12$ & 0.72 & $0.62 \pm 0.06$ \\
\hline Cellulose-glucose & 0.21 & 7.40 & 0.03 & $0.03 \pm 0.01$ \\
\hline
\end{tabular}

shown in Table 5. From these results values for the proportions of duodenal carbohydrate constituents derived from the bacteria were calculated and are also shown. Similar calculations were made for the other experiments and the mean values ( \pm SEM) for them all are also given in Table 5. It appeared that nearly all the rhamnose, mannose and ribose and about half the galactose and glucose came from bacterial synthesis, whereas nearly all the arabinose, xylose and cellulose-glucose was contributed by the diet.

\section{DISCUSSION}

Experiments done a number of years ago demonstrated the possibility of glucosecontaining polysaccharides accumulating in rumen bacteria (Howard, I955; Thomas, 1960; Hungate, I963). Conclusions that microbial synthesis contributes little to the polysaccharides entering the duodenum of the ruminant have been made usually on the basis of observations of bacterial composition in animals receiving all- or mainly-roughage diets (Heald, 195 I ; Singh \& Trei, I970; Porter \& Singleton, I97I). Thompson \& Hobson (197I) suggested, from in vitro studies, that, with highconcentrate diets, the rumen bacteria could provide a sheep with $25 \mathrm{~g}$ starch-like polysaccharide/d. This possibility, indicating that under some circumstances ruminants may derive useful amounts of glucose from rumen microbial synthesis, is supported by the results of Jouany \& Thivend ( $1972 b$ ) who found concentrations of combined glucose of up to $200 \mathrm{~g} / \mathrm{kg}$ dry matter in mixed bacteria separated from the rumens of cows receiving diets high in digestible carbohydrate. Further support for this view is provided by our finding that the rumen bacteria of calves, kept in our experimental calf-house (environment $A$ ) and given a roughage-cereal diet 
containing about $16 \mathrm{~g}$ nitrogen $/ \mathrm{kg}$ dry matter, had a high content of a carbohydrate ( $140 \mathrm{~g} / \mathrm{kg}$ dry matter) from which glucose was liberated by mild acid hydrolysis. Variations in the amounts of this carbohydrate in rumen bacteria developing under different conditions (discussed below) indicated that it was probably a storage material. The fact that amounts of most of the bacterial non-glucose sugars did not show similar variations suggested, on the other hand, that these formed part of the cell structure. The role of galactose was uncertain and it sometimes varied in amount, in parallel with glucose. Thus, although the storage carbohydrate is measured in terms of its glucose content and is referred to as $\alpha$-dextran, it is possible that it also contained a small amount of galactose. Whether $\alpha$-dextran is available as a glucose source for the host animal has not been directly demonstrated but seems probable. The glucose liberated by mild acid hydrolysis from duodenal contents was also released by $\alpha$-amyloglucosidase and was extensively digested in the small intestine (McAllan \& Smith, unpublished results). For our calves, over half of this was calculated to have been provided by microbial $\alpha$-dextran (Table 5).

In making this calculation we assumed that mixed bacterial samples separated from the rumen were representative of all the rumen micro-organisms. This assumption might be seriously in error if considerable amounts of protozoa were present; some ciliate protozoa are known to be able to accumulate large amounts of polysaccharide (Masson \& Oxford, I95I; Oxford, 195I ; Jouany \& Thivend, I972a) and we found that one sample of an Entodinium separated from a barley-fed steer contained $470 \mathrm{~g} \alpha$-dextran-glucose/kg dry matter (unpublished observation). If protozoa were present, therefore, our calculations might be expected to lead to an underestimate of microbial $\alpha$-dextran at the duodenum. Our environment A calves, however, did not generally contain protozoa (Smith \& McAllan, I974) so that our calculations were not in error from this cause.

It has been shown (Smith \& McAllan, 1974) that mixed rumen bacterial samples from environment $A$ calves contained more than twice as much $\alpha$-dextran as samples from calves kept near adult sheep but otherwise treated in an identical way. This appeared to be related to the fact that protozoa were absent from the environment $A$ calves but not from the other calves. A similar effect almost certainly accounted in part for the finding that bacteria from the environment $A$ calves contained more $\alpha$-dextran than bacteria from cows and sheep similarly fed. Differences in bacterial composition due to differences in the types of carbohydrate in the diet were, however, also apparent, and cows given high-cereal diets (more than $70 \%$ of their energy intake) had rumen bacteria containing as much $\alpha$-dextran as those from the environment A calves (Fig. 4). Whether this was due to a direct effect of the diet or to depression of the protozoal population by the high cereal intake of the cows (Latham, Sharpe \& Sutton, 1971) is not clear. At the other extreme, sheep and cows receiving all- or mainly-roughage diets had rumen bacteria with very low $\alpha$-dextran contents, a finding which agreed with the observations of Heald (195 I), Porter \& Singleton (1971) and Jouany \& Thivend ( $1972 b)$.

A further dietary effect on bacterial $\alpha$-dextran demonstrated for the calves was due to variations in the nitrogen content of the diet (Table 3). The results can be 
interpreted as showing that, during the period up to $4^{-6} \mathrm{~h}$ after feeding, microbial growth in the rumen was limited by the available nitrogen when the diets were based on unsupplemented cereals. Under these conditions the bacteria stored carbohydrate (as $\alpha$-dextran) in excess of their requirements. From in vitro experiments with sheep rumen fluid and from in vivo experiments with sheep, Walker (1968) and Walker \& Nader ( $977^{\circ}$ ) also concluded that, under conditions occurring shortly after feeding, in which an excess of readily fermentable carbohydrate is present, only a small part of the energy available from fermentation is used for protein synthesis, the greater part being used for synthesis of intracellular polysaccharide.

The provision of various dietary nitrogen supplements reduced the extent of this storage, presumably because the available carbohydrate was now used for synthesis of microbial protein, etc. Results were insufficient to show differences between the nitrogen supplements used, but other experiments have shown that supplementing a diet with casein treated with formaldehyde did not reduce the $\alpha$-dextran content of the rumen bacteria $4^{-6} \mathrm{~h}$ after feeding (Williams, McAllan \& Smith, 1973), presumably because this material failed to provide the bacteria with an available source of nitrogen.

Diurnal variations in the $\alpha$-dextran content of the rumen bacteria (Figs. 3 and 4 ) similarly implied that this material was used by the bacteria as an energy store and fluctuated in amount according to the energy required by, or supplied to, the organisms.

Our results do not, in themselves, provide information on absolute amounts of glucose provided to an animal by microbial synthesis. It can, however, be estimated on the basis of $24 \mathrm{~h}$ flows of RNA at the duodenum, measured in other experiments for similarly fed calves (J. L. Black, unpublished observation) that, in our environment A calves, about $100 \mathrm{~g}$ bacterial $\alpha$-dextran-glucose/d probably entered the duodenum. For an assumed digestibility of $65 \%$ (McAllan \& Smith, unpublished observation) this corresponded to an entry into the body of about $65 \mathrm{~g}$ glucose/d.

We thank Mrs S. J. Askew for supervising the conduct of many of the animal experiments, Dr H. L. Buttle and Mr S. C. Watson for carrying out all surgical operations, Mrs R. J. Fulford for the statistical treatment and Drs J. A. Bines and D. A. Corse for access to fistulated cows and sheep. We also thank Mr R. J. Merry and Miss P. E. Lewis for skilled technical assistance.

\section{REFERENCES}

Balch, C. C. \& Cowie, A. T. (1962). Comell Vet. 52, 206.

Doetsch, R. N., Howatd, B. H., Mann, S. O. \& Oxford, A. E. (1957). F. gen. Microbiol. x6, I56.

Doetsch, R. N., Robinson, R. G., Brown, R. E. \& Shaw, J. C. (1953). F. Dairy Sci. 36, 8z5.

Gibbons, R. J., Doetsch, R. N. \& Shaw, J. C. (x955). F. Dairy Sci. 38, I 147 .

Heald, P. J. (195 I). Br. F. Nutr. 5, 84 .

Hobson, P. N. \& Mann, S. O. (1955). F. gen. Microbiol. 13, 420.

Howard, B. H. ( 955 ). Biochem. $\mathscr{7} .60$, i.

Hungate, R. E. (1963). F. Bact. 86, 848.

Jouany, J-P. \& Thivend, P. (1972a). Annls Biol. anim. Biochim. Biophys. 12, 673.

Jouany, J-P. \& 'Thivend, P. (1972 b). Annls Biol. anim. Biochim. Biophys. 12, 679. 
Latham, M. J., Sharpe, M. E. \& Sutton, J. D. (1971). J. appl. Bact. 34, 425.

McAllan, A. B. \& Smith, R. H. (I969). Br. J. Nutr. 23, 67I.

McAllan, A. B. \& Smith, R. H. (1971). Proc. Nutr. Soc. 31, 24A.

McAllan, A. B. \& Smith, R. H. (1973). Br. F. Nutr, 29, 331

MacRae, J. C. \& Armstrong, D. G. (1968). F. Sci. Fd Agric. 19, 578.

Masson, F. M. \& Oxford, A. E. (195I). J. gen. Microbiol. 5, 664.

Oxford, A. E. (195I). F. gen. Microbiol. 5, 83 .

Porter, P. \& Singleton, A. G. (1971). Br. 7. Nutr. 26, 75.

Singh, Y. K. \& Trei, J. E. (1970). F. Anim. Sci. 3I, 253.

Smith, R. H. (r969). J. Dairy Res. 36, $3{ }^{1} 3$.

Smith, R. H. \& McAllan, A. B. (Ig66). Br. F. Nutr. 20, 7o3.

Smith, R. H. \& McAllan, A. B. (1969). Automation in Analytical Chemistry (Technicon Internationat Symposium, 1969) p. 207. Basingstoke, Hants: Technicon Instruments Company Ltd.

Smith, R. H. \& McAllan, A. B. (1970). Br. F. Nutr. 24, 545.

Smith, R. H. \& McAllan, A. B. (I971). Br. F. Nutr. 25, I81.

Smith, R. H. \& McAllan, A. B. (1974). Br. F. Nutr. 31, 27.

Thomas, G. J. (1960). F. agric. Sci., Camb. 54, 360 .

Thompson, J. K. \& Hobson, P. N. (1971). F. agric. Sci, Camb. 76, 423 .

Walker, D. J. (1968). Appl. Microbiol. 16, 1672.

Walker, D. J. \& Nader, C. J. (1970). Aust. F. agric, Res, 21, 747.

Williams, A. P., McAllan, A. B. \& Smith, R. H. (1973). Proc. Nutr. Soc. 32, 85 P. 